\title{
The short-term effect of store-level promotions on store choice, and the moderating role of individual variables
}

\author{
Pierre VOLLE \\ Assistant Professor of Marketing, \\ DMSP Research Center, Paris Dauphine University
}

Place du Maréchal de Tassigny 75775 - Paris - FRANCE Tel : 0033144054429 e-mail : volle@dauphine.fr

\footnotetext{
The author wishes to thank Pierre Desmet and Bernard Pras (Paris Dauphine University and ESSEC), Bruce Hardie (London Business School) and Gilles Laurent (HEC School of Management) for their insightful comments. He gratefully acknowledges the guidance provided by Fred van Raaij, the Editor, and JBR anonymous reviewers. The author finally thanks SECODIP (SOFRES) for providing the data, and the FNEGE (Fondation Nationale pour l'Enseignement de la Gestion des Entreprises) for its financial support.
} 


\title{
The short-term effect of store-level promotions on store choice, and the moderating role of individual variables
}

\begin{abstract}
The short-term effect of store-level promotions (weekly flyers, radio and outdoor advertising) on grocery store choice is investigated. We estimate household-level multinomial logit models of store choice on panel data, using promotional variables, loyalty and psychographic moderating variables. The research shows that the short-term effect of store-level promotions on store choice is significant but weak: store choice is mainly driven by loyalty. While we fail to demonstrate the moderating role of psychographic variables (involvement toward shopping, attitude toward the purchase of products on promotion, search for promotional information), however, the quasi-moderating role of loyalty is clearly validated. From a managerial point of view, adapting store-level promotions to individual characteristics does not seem to be relevant. Nevertheless, further research should be conducted in order to take into account the potential interactive effects of individual variables in a more systematic way, for example though a latent class analysis.
\end{abstract}


Store promotions are a way of life for retailers. Indeed, an intensive promotional activity allows the store to maintain / increase its turnover by achieving a higher penetration rate in the market area, an increase in the frequency of visits and / or an increase in the average amount spent in the store. Despite high fixed costs (e.g., organization, communication), promotions are a source of additional margins, thanks to the financial support of producers, and the speculative stocks that are constituted during the promotional periods. Moreover, store-level promotions help reinforce a low-price positioning, a key to performance. While the use of an "Everyday Low Price " strategy is another way to achieve such a positioning, it has been shown that such a strategy leads to an increase in sales at the expense of a substantial loss in profit (Hoch, Drèze and Purk, 1994).

Despite a few studies (Kumar and Leone, 1988; Walters, 1991; Mulhern and Padgett, 1995), the impact of storelevel promotions on household store choices is an under-explored area (Blattberg, Brietsch and Fox, 1994). Here, we wish to raise two questions. Firstly, are store choices influenced by store-level promotions? Secondly, do some individual variables (past behaviors and psychographics) explain whether some households react more than others to store-level promotions? We consider that three conditions have to be met simultaneously for a given promotional campaign to be considered as a "store-level promotion ": (1) the deals are real i.e., they are not only advertised regular prices (2) a portfolio of products is promoted, not an isolated brand or a product category (3) at least one external media is used, like a flyer, a radio or an outdoor advertising.

In the following sections, we first put into perspective the various studies dealing with store promotion and store choices, and develop the research agenda (Section 1). We then develop the theoretical perspective adopted in this research (Section 2) and propose a set of hypotheses (Section 3). Lastly, we discuss the methodology, the data and the measures (Section 4), we present the results (Section 5), and we conclude with a brief discussion (section 6).

\section{The research objectives}

According to Blattberg, Brietsch and Fox (1994), “ it is acknowledged that store promotions generate additional traffic, that leads to the purchase of complementary products at full-margin; nevertheless, it has never been proven". Indeed, Walters and Rinne (1986) demonstrate that cutting prices of 10 portfolios of products in 3 stores (i.e., 30 cases) only led to 2 cases where the traffic increased significantly, whereas Walters (1988) shows that only the impact of direct mail promotions on traffic is positive, but that advertised promotions have no impact. Mulhern and Leone (1990) reveal that a change in strategy - from " many products / low discounts " to " a few products / deep discounts " - lead to an 
increase in sales, without any significant increase in traffic. Finally, for Walters (1991), "in a majority of the cases, no interstore substitution effects involving the same brand or a substitute brand were detected “.

Briefly stated, previous research tends to demonstrate that the impact of sales promotions on traffic is ambiguous - at best weak - whereas conventional wisdom suggests the contrary. Still, some limitations could partially explain this intriguing conclusion. First, previous studies did not consider portfolios of product categories on deal, but only specific brands of coffee, biscuits, orange juice, detergent etc. (e.g., Kumar and Leone, 1988; Bucklin and Lattin, 1992). Second, most research does not explicitly consider promotional activities from competing retailers (e.g., Kumar and Leone, 1988; Walters, 1991; Mulhern and Padgett, 1995). Third, most studies do not consider radio and outdoor advertising, despite their importance in communication budgets of retailers (e.g., Berman and Evans, 1989; Jallais and al., 1994).

Our objective is to determine the role of situational variables on the store choice (e.g., number of products on promotion, radio and outdoor advertising) and the moderating role of individual variables (e.g., past behaviors and psychographics) on the relation between store-level promotion and choice probabilities. We leave aside two issues of further interest i.e., the frequency of visit, and the overall basket value. We believe this research is original for various reasons: (a) we focus on the retailer, since the stimulus under consideration is a portfolio of promo ted products, and not a brand or a product category (b) the promotional stimulus is complete and realistic, representing both the substantive deals and the supporting communication (c) household-level data on behaviors and psychographics are combined (d) and last, research published so far aimed mostly at modeling the traffic, the sales volume or the profit at the store level, but not at explaining deal-proneness to store promotions at the household level.

\section{The theoretical perspective}

The interactionist paradigm - Most of the research dealing with store choice involve the gravitational and / or the attitudinal attraction theories. According to these theories, patronage depends on size and distance (gravitational attraction), or on the individual preference toward the store's attributes (attitudinal attraction). Indeed, many studies demonstrate the impact of distance on store choice (e.g., Hirschman and al., 1978; Arnold and al., 1983; Black and al., 1985; Fotheringham and Trew, 1993; Desmet and Volle, 1996), while store image explains choices significantly (e.g., Korgaonkar and al., 1985; Hildebrandt, 1988). Nevertheless, neither the gravitational nor the attitudinal theory of attraction is able to account for short-term variations in patronage behavior; these variations can not be accounted for by differences in location or store image, which are necessarily stable in the very short-term. As a consequence, neither 
the distance and the size, nor the attitude are introduced explicitly in the model; the impact of distance and attitude are not considered per se, but incorporated through the concept of loyalty. Following Guadagni and Little (1983), we consider (store) loyalty directly, because this variable has the desirable property of incorporating long term utility (e.g., geographical separation, inherent preference toward the store attributes etc.), as well as short term behavioral changes (e.g., response to a promotional offer).

The interaction between the individual and the situation has been shown to explain a substantial part of the variance in observed behaviors (Bowers, 1973; Belk, 1975; Punj and Stewart, 1983). For interactionist theorists, the "psychological meaning " attributed by individuals to situations is a key determinant of their behaviors. Following this theoretical perspective, we thus believe that a combination of situational (i.e., store-level promotions) and individual factors (i.e., moderating variables) can explain store choice behaviors, in addition to more traditional variables (e.g., distance or attitude considered through the loyalty variable). However, in this research, the principle of “psychological meaning " is simply implemented through the notion of moderating variables (Sharma, Durand and GurArie, 1981; Baron and Kenny, 1986); indeed, we later hypothesize that these moderating variables change the perception of store-level promotions. For example, a customer highly motivated by shopping will view store promotions with a higher interest, and then may be more responsive; he / she basically attributes certain positive meanings to the "store promotions" situation. Implementing the interactionist paradigm requires deciding on the relevant variables to be included in the conceptual model. We present these variables below, discussing the situational variables and then the individual variables of interest. A more detailed presentation of the variables is given in section 3, when the hypotheses are derived.

The situational variables - As far as grocery shopping is concerned, we postulate that store-level promotions are "unexpected events " (Sheth, 1983) and that most shoppers do not anticipate them; as such, they are not part of the store ongoing positioning (Mulhern, 1997), and therefore can be considered as situational variables (Belk, 1975). We only consider store-level promotions in this research, assuming that other situational variables are randomly controlled (e.g., crowding, antecedent mood) or stable (e.g., opening hours) during the period under investigation. Further, we not only consider the presence / absence of store-level promotions, but their "intensity “. Here, the overall store promotional intensity is a joint function of the intensity of (a) the deals offered to the customers and (b) the supporting communication (Desmet, 1992). 
The individual variables - As far as store choice is concerned, only a few moderating variables have yet been considered: distance to the store (e.g., Kumar and Leone, 1988), type of visit (Kahn and Schmittlein, 1992), and store loyalty (Grover and Srinivasan, 1992). In this research, we evaluate the moderating role of store loyalty, as it is a key variable accounting for the effects of gravitational and attitudinal attraction. Secondly, we evaluate the role of a set of individual moderating variables which role has been proven in the brand choice context but not yet in the store choice context; these psychographic variables are the enduring involvement toward grocery shopping, the attitude toward the purchase of products on promotion, and the search for promotional information. We justify in the next section that these individual variables may amplify or reduce the impact of store-level promotions on store choice, as they induce a specific framing of the situation by the customers.

The situational and the individual variables considered in this research are summarized below (Figure 1). In the following section, we develop the set of hypotheses around these variables.

\section{$<$ Insert Figure 1 >}

\section{Research hypotheses}

Store-level promotions as explanatory variables - Building on the brand choice literature (Mazumbar and Yun, 1993), we suggest that all things being equal, the intensity of a multi-item deal varies according to the number of products presented. In addition, we believe that the number of advertised products gives a fair indication of the overall store promotional intensity to the customers. Here, we do not distinguish between the types of promotions, as Diamond (1992) demonstrates that consumers have the same preference for price cuts and extra-product offers. We propose the following hypothesis:

H1 - The number of promoted products proposed in a given flyer has a positive effect on store choice probabilities.

As some products presented in these flyers are not explicitly promoted (i.e., no indication of any special price or extra-product offer), we also hypothesize that the sheer number of products, whether on promotion or not, influence store choice. We thus propose the following hypothesis:

H2 - The number of products proposed in a given flyer has a positive effect on store choice probabilities.

Further, Yadav (1994) observes that the better the anchoring product, the better the overall perception of a bundle (i.e., anchoring and adjustment heuristic). Still, the question is to determine which products are susceptible to positively influence the overall perception of the promoted portfolio. Based on the Central Place theory (Hubbard, 1978), 
we suggest that higher price / lower frequency products influence positively the perception of the store promotional intensity. We consider the number of non-food products as a proxy for these "long range " products that are held to attract customers from a longer distance.

H3 - The number of "long range " products proposed in a given flyer has a positive effect on store choice probabilities.

Store promotional communication as an explanatory variable - The simultaneous use of media has been found to enhance the effectiveness of brand promotions (e.g., Moriarty, 1983; Walters, 1988; Bemmaor and Mouchoux, 1992). Inman, McAlister and Hoyer(1990) show that through a signaling effect, the sole announcement of a promotion with no real deal increases the intention to purchase (the effect is stronger when the announcement is accompanied with a special-price offer). Walters and McKenzie (1988) demonstrate the amplifying effect of direct marketing on sales promotions in the retailing context. Therefore, although there is no direct study to support this view, we hypothesize that investments in radio and outdoor advertising also produce positive and interactive effects on choice probabilities. We propose the following hypotheses, to test for an extension of the above results to the context of store choice:

H4 - Radio advertising has a positive effect on store choice probabilities.

H5 - Outdoor advertising has a positive effect on store choice probabilities.

H6 - The interaction between radio and outdoor advertising has a positive effect on store choice probabilities.

Store loyalty as a quasi-moderating variable - Store loyalty is a quasi-moderating variable, because of its double effect on store choice probabilities: (a) directly, through a main effect on the probability to choose the store and (b) indirectly, through an interaction with the promotional variables. Concerning the main effect, Guadagni and Little (1983) demonstrate that loyalty strongly influences brand choices. We intend to extend this result to the choice of stores, and more importantly, we wish to determine the role of store loyalty, relative to the other explanatory variables included in the choice model. Concerning the moderating effect, Mittal (1994) observes that the higher the loyalty to a given store, the higher the cost to switch to another; therefore, a customer will probably not respond favorably to the deals coming from a store he / she does not patronize already. Similarly, this shopper will not be influenced by deals coming from a store he / she already patronizes regularly, since he / she would probably patronize the store anyway (Froloff-Brouche, 1994). As Ortmeyer, Lattin and Montgomery (1991) put it for brand choice, “the impact of promotion on utility will be less when the individual does not prefer the brand, or, conversely, when the individual prefers the brand very strongly (and does not prefer other brands) “. Here, we hypothesize that:

H7 - Loyalty toward a given store has a positive effect on store choice probabilities. 
H8 - The effect of the number of products proposed in a flyer on store choice probabilities will be higher for shoppers with an intermediate level of loyalty.

Involvement toward shopping as a moderating variable - The concept of involvement is certainly as relevant for stores as it is for products (Ducrocq, 1991). Indeed, Peterson and Power(1995), measure the involvement toward 41 services, and show that the involvement toward supermarket shopping is above the average, as well as much higher for supermarkets than for other types of stores. As the level of involvement varies by store type and product category (Laurent and Kapferer, 1985), the enduring involvement is not a stable trait, but results in the interaction between a type of product and a type of store. In this research, we empathize the purchasing activity rather than the type of product bought; however, we do not consider each dimension separately i.e., functional / economic, hedonic / recreational or social (Tauber 1972; Westbrook and al., 1985; Bergadaà, Perrien and Faure, 1995). We suggest that consumers involved by the shopping activity, may pay more attention to promotional offers, and hence are more responsive. Moreover, as enduring involvement toward shopping is associated with greater economic motivations (Bergadaà, Perrien and Faure, 1995; Tat, 1994), we also suggest that involved shoppers are more deal-prone. Indeed, Urbany, Dickson and Kalapurakal(1996) demonstrate that customers who enjoy shopping tend to have a cherry picking behavior (1.e., systematically shop for specials). As a consequence, we propose the following hypothesis:

H9 - The effect of the number of products proposed in a flyer on store choice probabilities will be higher for customers involved toward shopping.

Attitude toward the purchase of products on promotion as a moderating variable - Shimp and Kavas (1984), as well as Mittal (1994) find a positive relation between the attitude toward, and the effective use of coupons. Schneider and Currim (1991) also establish a link between deal-proneness and efficiency of displays and features, whereas Lichtenstein and al. (1993) demonstrate that high sale/coupon-proneness leads to an increase in the purchase of promoted products. Here, we consider the attitude as a global affective evaluation toward the act of purchasing a product on promotion, and as a matter of simplification but contrary to published results, we postulate that the attitude toward promotions is the same whatever the type of promotion (Henderson, 1994), or the product category considered (Bawa and Shoemaker, 1987). We extend the above results to store choice, and thus propose the following hypothesis:

H10 - The effect of the number of products proposed in a flyer on store choice probabilities will be higher for customers with a favorable attitude toward the purchase of products on promotion.

Search for promotional information as a moderating variable - External information comes from many sources (Beatty and Smith, 1987): salespeople, media, neutral sources, family and relatives. For grocery shopping, professional data indicates that a high proportion of the communication budgets goes into flyers (Berman and Evans, 1989; Jallais 
and al., 1994). Consequently, determining whether a customer searches for promotional information when shopping will be inferred from his / her use of flyers ${ }^{1}$. We suggest that skimming through, or even reading the flyers is a necessary condition - however not sufficient - for the shoppers to become aware of the store-level promotions before deciding which store to patronize. Further, the promotional information may also help the store to enter in the consideration set of some shoppers, who otherwise would not have considered a visit (Siddarth, Bucklin and Morrison, 1995). We thus propose the following hypothesis:

H11 - The effect of the number of products proposed in a flyer on store choice probabilities will be higher for customers who claim searching for promotional information.

Having presented the hypotheses stemming from the application of the interactionist perspective to store-level promotions and store choice, we give some methodological details below.

\section{Methodology, data, and measures}

Methodology - Household store choice probabilities are modeled within a multinomial logit framework in order to account for the impact of past behaviors (i.e., individual variables) along with the effect of store promotional activities (i.e., situational variables); in this respect, the MNL model seems well adapted to implement the interactionist paradigm. This model has been used several times to model store choice (Arnold and al., 1983; Grover and Srinivasan, 1992; Bucklin and Lattin, 1992; Fotheringham and Trew, 1993), although it is known to have some limitations ${ }^{2}$. Here, we implement several procedures to partially avoid these limitations: loyalty variables are introduced in the MNL model to account for individual preferences toward the competing stores, and consideration sets are established for each household based on past choices during a 6 months initialization period. A test for the absence of IIA is carried out with LIMDEP 7 (Ben Akiva and Lerman, 1985, P. 184); we obtain an acceptable result, in comparison to other studies (e.g., Guadagni and Little, 1983; Gupta, 1988; Bucklin and Lattin, 1992; Desmet, 1993), and considering the large number of observations (i.e., more than 38,000).

The procedure used to test the hypotheses involves three steps. The first step consists in introducing the loyalty variable along with the store-specific constants in order to obtain a base model comparable to the Guadagni and Little (1983) benchmark model. The second step consists in introducing the promotional variables in the model, in order to test $\mathrm{H} 1$ through $\mathrm{H} 6$. The third step consists in introducing the individual moderating variables to test H8 to H11; only the test for the moderating role of loyalty is worth a specific comment. Following Ortmeyer, Lattin and Montgomery (1991), three conditions have to be met for the moderating role of store loyalty to be demonstrated (i.e., inverted U-shape 
relation): the main effect (number of products) and the interaction effect (number of products $\mathrm{x}$ loyalty) must be significant and positive, whereas the squared interaction effect (number of products $\mathrm{x}$ squared loyalty) have to be significant, but with a negative sign (further details are given in the original reference).

Data and measures - The behavioral data provided by SECODIP (SOFRES Group) originate from an instrumented market i.e., a small to medium sized city with scanners in all major grocery stores (Château-Thierry, France). Five competing discount stores ranging from $1,200 \mathrm{~m}^{2}$ to $4,500 \mathrm{~m}^{2}$ represent more than $90 \%$ of the local grocery market. The last 6 months of 1994 are used for initialization of the loyalty variable, while the first 6 months of 1995 are used for estimation. There were 1,176 households in the initial sample; however, the 212 customers entirely loyal to one store where not considered at the modeling stage (these customers should be studied separately as their consideration set is equal to one). Hence, our sample contains 964 households, who made 38,218 visits from January to June 1995 . Each record indicates the household identification number, the store visited, the date of the visit, the number of items purchased, and the amount spent for the particular shopping trip (some information were not used in this particular study). Motivational and attitudinal variables were measured through a questionnaire sent in February 1996 to the same households as for the behavioral panel. Eight households not participating to the panel were asked to collect the flyers delivered at their home during the first 6 months of 1995; they were rewarded with about $\$ 20$. Finally, a panel of 50 outdoor posters located in the instrumented market was set up, and the programs of a major French radio were weekly taped during Fridays, in order to collect the information about radio advertising ${ }^{3}$.

Concerning the operationalization of the variables, we first measured loyalty following the Guadagni and Little (1983) approach i.e., exponential smoothing over the reference period. However, unlike most studies, the smoothing parameter $\alpha$ was estimated according to the Non-linear Estimation Algorithm proposed by Fader, Lattin and Little (1992). Within 4 iterations, we ended-up with an estimated value $(\alpha=0.905)$ which is significantly higher than the brand-loyalty parameters published so far (e.g., Guadagni and Little, 1983; Desmet, 1993). The overall level of enduring involvement toward shopping was measured with a scale that accounts for the relevance, the attractiveness and the interest of the activity under consideration; the original enduring involvement scale (Strazziéri, 1994) was shortened and adapted to the context of grocery shopping (3 items). Concerning the attitude toward sales promotion, Mittal (1994) demonstrates that the variance in the attitude toward coupons is better explained by the enjoyment feeling than by time costs; this illustrates the interest in using the affective dimension of attitude, parallel to costs / benefits beliefs. Further, our 2 items distinguish the intrinsic enjoyment while hunting for promotions, from the "smart shopping " feeling (Schindler, 1984). Finally, the search for promotional information was measured through the use of flyers (3 items). All these items are 
presented in appendix $\mathrm{A}^{4}$. The reliability of the scales measured by the Cronbach' alpha is satisfactory (Table 1$)$. A principal component analysis (VARIMAX rotation, Kaiser criteria) indicates that the discriminant validity is acceptable, as well as the convergent validity (Table 2).

\author{
< Insert Table 1 > \\ < Insert Table 2 >
}

\title{
5. Results of the research
}

We present the loyalty-only benchmark model first. While doing so, we also test the main effect of store loyalty on store choice probabilities (H7). We then investigate the main effect of store-level promotions on choice probabilities (H1 to H6). Lastly, we examine the moderating role of store loyalty, enduring involvement toward shopping, attitude toward the promotions and search for promotional information (H8 to H11).

The loyalty-only benchmark model - The estimation of a first model (Table $3 a$ ) with the store-specific constant ${ }^{5}$ and the loyalty variable shows a very satisfactory fit (adjusted $\rho^{2}=0.59$ ). More specifically, the empirical investigation reveals that the effect of loyalty (LOY) on store choice probabilities is highly significant; $\mathrm{H}_{7}$ is therefore validated ${ }^{6}$.

\section{< Insert Table 3 >}

The role of situational variables - We introduce the situational variables and estimate a second multinomial logit model (Table 3b). This analysis reveals that the introduction of the store-level promotional variables improves the model significantly. Indeed, the likelihood ratio test is significant (Ben Akiva and Lerman, 1985, p. 166), as -2[L(3a)-L(3b)] equals 46.4 , which is greater than the theoretical value $\chi^{2}=18.55$ with 6 degrees of freedom). More specifically, the parameters for the number of products on promotion (PROMO) is significant at $\mathrm{p}<0.1$ while the coefficient for the number of products (PROD) is significant at $\mathrm{p}<0.05$. However, the coefficient for the number of non-food "long range " products (LR_PROD) is not significant. Hypotheses H1 and H2 are thus validated, whereas hypothesis H3 is rejected. Concerning the communication variables, the parameters for radio advertising (RAD_AD) and for outdoor advertising (OUT_AD) are not significant. Considering the lack of empirical support, hypothesis H4 and H5 are thus rejected. On the other hand, H6 can not be rejected as the coefficient of the interaction term (RAD x OUT) is significant at $p<0.1$; the simultaneous use of radio and poster advertising influences significantly the store choice probabilities ${ }^{7}$.

The role of individual variables - Overall, the introduction of the moderating variables in the base model (Table $3 c)$ improves the model significantly, as $-2[\mathrm{~L}(3 \mathrm{a})-\mathrm{L}(3 \mathrm{c})]=304.0$ for a theoretical value of $\chi^{2}=16.75$ with 5 degrees of 
freedom; however, store loyalty variables are entirely responsible for this result. Indeed, all three variables (PROD, PROD $\mathrm{x}$ LOY, PROD $\mathrm{x} \mathrm{LOY}^{2}$ ) are significant with the expected positive and negative signs (see above for methodological details). It means that the effect of promotions is higher for shoppers showing moderate levels of loyalty, than it is for shoppers showing either low or high levels of loyalty; as a consequence, H8 is validated. On the contrary, the moderating of the three psychographic variables - involvement toward shopping, attitude toward products on promotion, and search for promotional information - is not validated, as none of the parameters are significant at $\mathrm{p}<0.1^{8}$. Hypothesis H9, H10 and H11 are therefore rejected.

\section{Discussion and managerial implications}

Summary - The objectives of this research were twofold: we first aimed at demonstrating empirically the effect of store-level promotions on store choice probabilities, and then at establishing the role of individual moderating variables. The first issue receives an unequivocal answer; indeed, we find that the effect of store-level promotions on store choice probabilities is (at best) weak, compared to the inertia of household store choices. However intriguing, this conclusion drawn at the household level is consis tent with the literature dealing with aggregate traffic at the store level (e.g., Walters, 1991) or nested brand / store choices (e.g., Grover and Srinivasan, 1992). The second issue also obtained an unambiguous answer: store loyalty is the only individual variable considered here which is shown to moderate the effect of store-level promotions on store choice; following Ortmeyer and colleagues (1991), our data extends to store choice the idea that households showing an intermediate level of loyalty toward a given store are more deal-prone than weakly or highly-loyal households. Nevertheless, based on a sample of store choices, we fail to demonstrate the moderating role of three psychographic constructs i.e., enduring involvement toward shopping, attitude toward the purchase of products on promotion and search for promotional information. Our conclusion that these variables do not explain observed deal-proneness to store-level promotions is interesting because these very same variables are shown to be linked to declared deal-proneness. This later point, as well as other issues, is raised in the following discussion.

Discussion - First of all, as a general comment concerning the results obtained in this study, it must be said that falsifying research hypothesis like we do here, has to be considered as a challenging conclusion - otherwise, there is no point in testing hypotheses (Bowers, 1973) - specially when these hypotheses (i) seemed initially to be common sense and (ii) were inconclusive in the literature. Still, we must establish that this conclusion is not mostly due to methodological shortcomings. 
In fact, the methodology may partially explain why we failed to validate quite a large number of our hypotheses. First of all, the time unit chosen to analyze the store-level promotions may have been confusing, specially for the radio and outdoor advertising variables because of dynamic / lagged effects; however, a weekly time unit is widespread in academic research and make sense for retail managers. Second, estimation biases may have occurred as five competing stores with various sizes and locations were pooled; nevertheless, we remind the reader that our model is not subject to the IIA limitation. Third, we initially postulated that only the weekly absolute level of store-level promotional intensity should influence store choices; we did not consider the variation in promotional intensity as Guadagni and Little (1983) did, for example, with a price-variation variable. As an exploratory analysis, we introduce a new variable in the logit base model, i.e., the weekly variation in the number of advertised products. We conclude that the parameter is significant at the $\mathrm{p}<0.001$ level, and that the increase in fit is significant however low; this line of research seems to have some potential for additional investigation. Fourth, only the quantitative dimension of objective store-level promotional intensity was accounted for; neither the qualitative aspects (e.g., design of flyers, quality of radio ads, location of outdoor advertising) nor the perceived promotional intensity were considered here; these points ought certainly to be researched further.

Concerning more specific hypotheses, our definition of long range products as non food products may not be relevant; in particular, attractive products are not necessarily the same products for all shoppers; this again should be investigated further. Lastly, the moderating effects may have been significant, had we explicitly introduced the interactions between individual variables in a different modeling framework. As a matter of fact, the correlation between individual variables are all significant at the 0.01 level, reaching a high 0.419 between attitude toward promotions and search for promotional information; moreover, a relation between loyalty and involvement has been established in the brand choice literature (Knox and Walter, 1995). This last point should be examined in a framework where segmentation and estimation are carried out simultaneously (e.g., latent class models). Finally, although the data collected for this study are quite robust, our conclusions are only based on one market; this research should be conducted in other settings to guarantee a greater external validity.

However, the impact of store-level promotions is weak because most of all, we empirically demonstrate that store choices are surprinsigly stable in the short term; the effect of store-level promotions on the sub-sample of households visiting more than 2 stores $(n=474)$ is no more conclusive. Further, had the impact of store-level promotions been stronger, we would certainly have identified some inter-individual variations. Surprisingly enough, we measured the declared deal-proneness to store promotions in the questionnaire $(2$ items, $\alpha=0.74){ }^{9}$ and found a 
significant relationship between this measure and the psychographics; more specifically, we carried out a simple linear regression analysis, and established that involvement toward shopping is negatively associated with our measure of declared deal-proneness, whereas search for promotional information is positively related to it $\left(\mathrm{r}^{2}=0.23, \mathrm{~F}=98\right){ }^{10}$. This result illustrates the well-documented gap between declared and observed behaviors (Lutz, 1991) and raises some interesting questions about the difference between panel data and surveys for measuring adequately the effect of sales promotions on choice behaviors.

We conclude this discussion, with the investigation of two last objections which we think, are not empirically justified here. First, it can be argued that the lack of positive results comes from a lack of variation the independent variables; in other words, there are store-level promotions every week in every store. As a matter of fact, there are only 7 weeks out of $120^{11}$ without any store-level promotions, but there are 14 weeks without any promoted products, and 84 weeks without any radio or outdoor advertising; the promotional intensity is obviously not constant throughout the study. Concerning the promoted weeks, the diversity and the precision of the measures guarantees to capture the changes in promotional activity on a weekly basis. For example, the number of advertised products goes up to 768 for store 3 during week 12, that is up to 7 times the average number of advertised products (see figure 2 for an illustration about the two biggest stores investigated).

\section{$<$ Insert Figure 2 >}

The second objection deals with the fact that store loyalty should be measured free of consideration of the promotional activities (e.g., Ortmeyer, Lattin and Momtgomery, 1991 for a discussion); indeed, if a patron is loyal to a store because of an attractive and regular promotional activity, the store-level parameters will be close to zero in the logit model, which is obviously not reflecting his / her genuine deal-proneness. We suggest that if this patron is loyal to a store because of the promotional intensity, his / her should rationally visit different stores, because no store has the highest level of promotional intensity throughout the 24 weeks under investigation; hence, the parameters in the logit model would not be zero. When the store-level promotional variables are included without the store loyalty variable, the fit is acceptable (adjusted $\rho^{2}=0.45$ ) and the parameter are all very similar to those mentioned above. Therefore, the conclusion does not change; the store-level promotion variables do not explain much of store patronage choices in comparison to store loyalty.

Managerial implications - It has been established that store-level promotions hardly influence short-term store choice probabilities (i.e., these probabilities are probably driven by more structural variables, like size or location); still, 
does it mean that retailers should stop investing in store-level promotions? We believe that retailers are in competitive situations that are close to the prisoner dilemma: an intense store-promotional activity does not boost the traffic, whereas a long-term decrease would probably cause a significant drop in traffic, assuming that the competitors do not follow. Therefore, if we consider store-level promotions as a mutually accepted and necessary investment, with almost no consequences on traffic in the short term, retailers ought to maximize their return in a different perspective. Store-level promotions should certainly be viewed as a managerial tool devised to sustain the motivation of the store personnel, or a very efficient way to build, maintain, and carry a competitive price image without immediate measurable outcomes. Moreover, the potential effects of store-level promotions on the frequency of visit, and on the basket value remain to be investigated. We believe that the latter perspective may reveal particularly interesting conclusions. Another set of managerial implications comes from our second finding. Indeed, we have established that with the exception of loyalty, individual variables do not play a moderating role on the effectiveness of store promotions. This means that whatever their level of involvement, the extent of their information search, or the favorability of their attitude toward promotion, all customers will be responsive to store-level promotions in the same way. In other words, the study suggests that segmentation does not seem to be particularly relevant for store-level promotions. From a practical point of view, segmenting and adapting store-level promotions is probably not worth the extra budget (market research, targeting cost, administration costs...). However, as we demonstrate that store loyalty is a moderating variable, adjusting the store promotions to the loyalty level could be a viable option. If implementing such a segmentation scheme at the household level is not necessarily realistic, this could be done at the market-area level. Retailers could segment their portfolio of stores and for each store, their market areas based on the store loyalty performance, and adapt their promotional strategy accordingly (i.e., micro-marketing). In particular, store-level promotions should be concentrated in areas where the store performs moderately in term of store loyalty. 
Figure 1 - The conceptual model

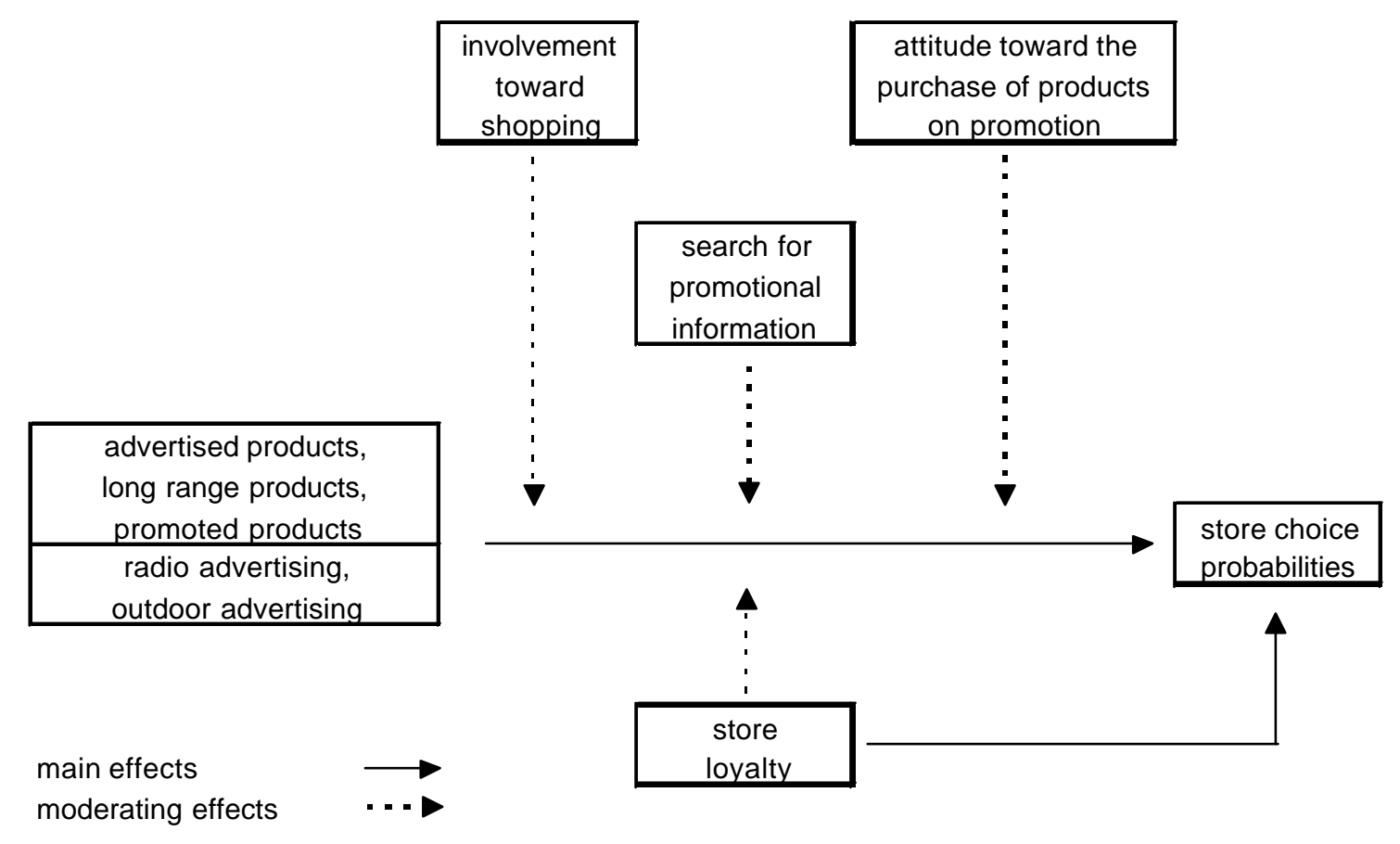


Figure 2 - Number of products proposed in the flyers

(24 weeks, stores $2 \& 3$ )

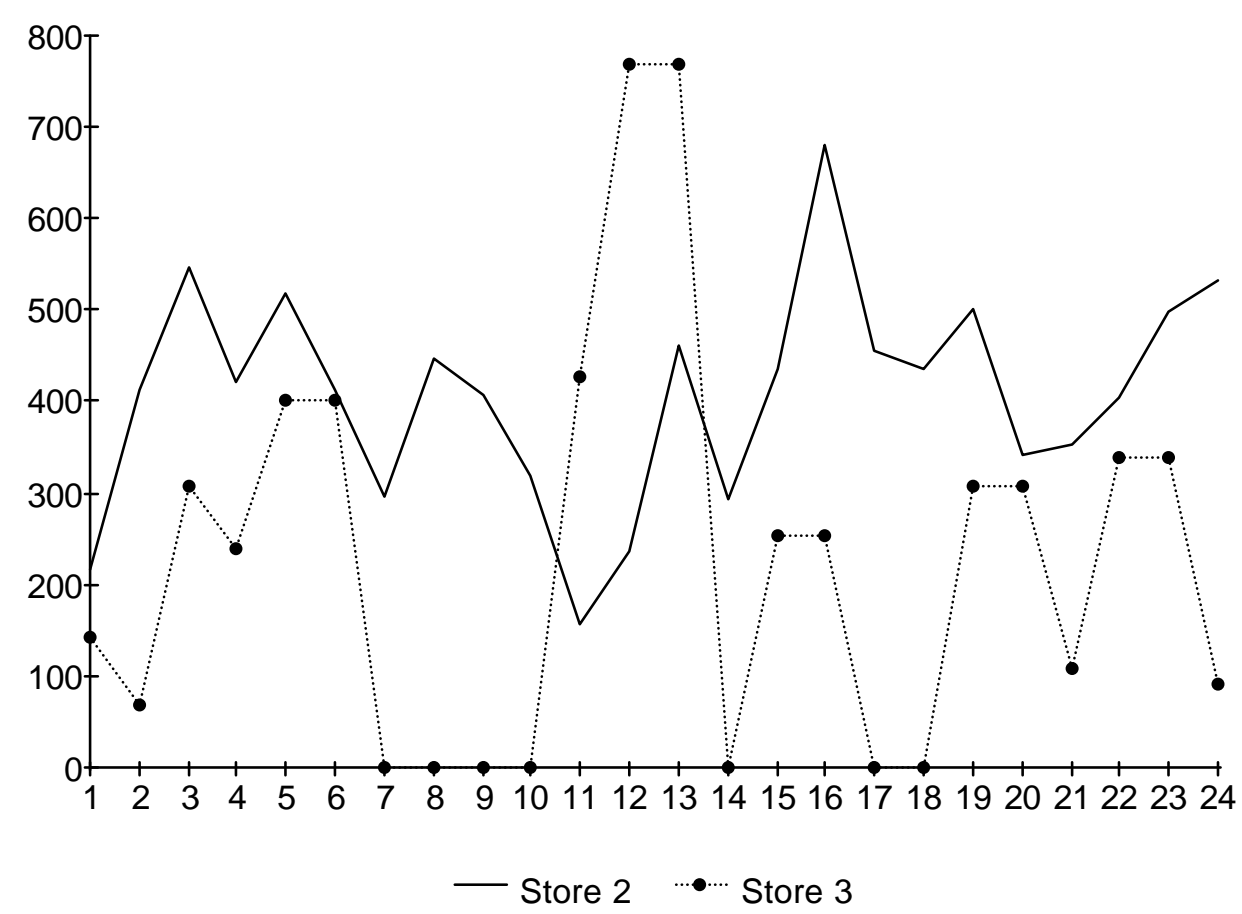


Table 1 - Reliability of the scales

Cronbach' $\alpha$

\begin{tabular}{|l|l|}
\hline Enduring involvement toward shopping & 0.83 \\
\hline Attitude toward the purchase of products on promotion & 0.76 \\
\hline Search for promotional information & 0.81 \\
\hline
\end{tabular}

Table 2 - Discriminant and convergent validity of the constructs

\begin{tabular}{|l|c|c|c|c|}
\cline { 2 - 5 } \multicolumn{1}{c|}{} & $\mathrm{F} 1$ & $\mathrm{~F} 2$ & $\mathrm{~F} 3$ & Communality \\
\hline INVOLVE_1 & 0.88 & & & 0.79 \\
\hline INVOLVE_2 & 0.80 & & & 0.68 \\
\hline INVOLVE_3 & 0.87 & & & 0.78 \\
\hline ATTITUDE_1 & $\left.{ }^{*}\right)$ & & 0.87 & 0.81 \\
\hline ATTITUDE_2 & & & 0.86 & 0.81 \\
\hline INFOSEARCH_1 & & 0.81 & & 0.74 \\
\hline INFOSEARCH_2 & & 0.85 & & 0.74 \\
\hline INFOSEARCH_3 & & 0.83 & & 0.71 \\
\hline Eigen value & 3.3 & 1.7 & 1.0 & \\
\hline \% variance & 40.8 & 21.8 & 12.9 & $\mathrm{~S}=75.6$ \\
\hline
\end{tabular}

(*) Loadings below 0.25 are omitted from this table. 
Table 3 - Estimation of the multinomial logit models

\begin{tabular}{|c|c|c|c|c|c|c|}
\hline & \multicolumn{2}{|c|}{ Table 3a } & \multicolumn{2}{|c|}{ Table 3b } & \multicolumn{2}{|c|}{ Table 3c } \\
\hline & \multicolumn{2}{|c|}{ Base model } & \multicolumn{2}{|c|}{$\begin{array}{c}\text { Base model }+ \\
\text { situational variables }\end{array}$} & \multicolumn{2}{|c|}{$\begin{array}{c}\text { Base model + } \\
\text { individual variables }\end{array}$} \\
\hline & coefficient & $\mathrm{p}[|\mathrm{Z}|=\mathrm{z}]$ & coefficient & $\mathrm{p}[|\mathrm{Z}|=\mathrm{z}]$ & coefficient & $\mathrm{p}[|Z|=\mathrm{z}]$ \\
\hline LOYALTY & 2.67 & 0.000 & 2.67 & 0.000 & 2.21 & 0.000 \\
\hline PROMOS & & & $0.32 \mathrm{E}-3\left(^{*}\right)$ & 0.075 & & \\
\hline PROD & & & $0.32 \mathrm{E}-3$ & 0.001 & $0.12 \mathrm{E}-2$ & 0.000 \\
\hline LONG RANGE PROD & & & - & n.s. & & \\
\hline RADIO ADS & & & - & n.s. & & \\
\hline OUTDOOR ADS & & & - & n.s. & & \\
\hline RADIO $\times$ OUT ADS & & & $0.62 \mathrm{E}-1$ & 0.070 & & \\
\hline PROD x LOYALTY & & & & & $0.57 \mathrm{E}-2$ & 0.000 \\
\hline PROD $x$ LOYALTY ${ }^{2}$ & & & & & $-0.39 E-2$ & 0.000 \\
\hline PROD x INVOLVEMENT & & & & & - & n.s. \\
\hline PROD x ATTITUDE & & & & & - & n.s. \\
\hline PROD x INFORMATION & & & & & - & n.s. \\
\hline STORE 1 & - & n.s. & - & n.s. & - & n.s. \\
\hline STORE 2 & -0.08 & 0.068 & -0.17 & 0.001 & -0.15 & 0.001 \\
\hline STORE 3 & -0.08 & 0.053 & -0.12 & 0.008 & -0.08 & 0.085 \\
\hline STORE 4 & -0.44 & 0.000 & -0.45 & 0.000 & -0.43 & 0.000 \\
\hline adjusted $\rho^{2}$ & 0.591 & & 0.591 & & 0.593 & \\
\hline L(Model) & $-25,170.8$ & & $-25,147.6$ & & $-25,018.8$ & \\
\hline
\end{tabular}

(*) These e-power coefficients are significant because of very small standard errors; 38219 observations were used for estimating the models (Standard Maximum Log-likelihood estimators with Limdep 7). 


\section{References}

Andrews, R.L., and Srinivasan, T.C.: Studying Consideration Effects in Empirical Choice Models Using Scanner Panel Data. Journal of Marketing Research 32 (February 1995): 30-41.

Arnold, S.J., Oum, T.H., and Tigert, J.D.: Determinant Attributes in Retail Patronage: Seasonal, Temporal, Regional and, International Comparisons. Journal of Marketing Research 21 (May 1983): 149-157.

Baron, R.M., and Kenny, D.A.: The Moderator-Mediator Variable Distinction in Social Psychological Research: Conceptual, Strategic and Statistical Considerations. Journal of Personality and Social Psychology 51 (1986): 1173-1182.

Bawa, K., and Shoemaker, W.: The Coupon-Prone Consumer: Some Findings Based on Purchase Behavior Across Product Classes. Journal of Marketing 51 (October 1987): 99-110.

Beatty, S.E., and Smith, S.M.: External Search Effort: An Investigation Across Several Product Categories. Journal of Consumer Research 14 (June 1987): 83-95.

Belk, R.W.: Situational Variables and Consumer Behavior. Journal of Consumer Research 2 (December 1975): 157-164.

Bemmaor, A.C., and Mouchoux, D.: Effet des réductions de prix and de la publicité sur les ventes en magasin : un plan factoriel. Recherche et Applications en Marketing 7 (1992): 27-47.

Ben-Akiva, M., and Lerman, S.R.: Discrete Choice Analysis. The MIT Press, Cambridge, MA. 1985.

Bergadaà, M., Faure, C., and Perrien, J.: Enduring Involvement with Shopping. The Journal of Social Psychology 135 (1995): 17-25.

Berman, B., and Evans, J .R.: Retail Management. Macmillan, $4^{\text {th }}$ Edition. 1989.

Biswas, A., and Blair, E.A.: Contextual Effects of Reference Prices in Retail Advertisements. Journal of Marketing 55 (July 1991): 1-12.

Black, W.C., Ostlund, L.E., and Westbrook, R.A.: Spatial Demand Models in an Intrabrand Context. Journal of Marketing 49 (1985): 106-113.

Bowers, K.S.: Situationism in Psychology: an Analysis and a Critique. Psychological Review 80 (September 1973): $307-$ 336.

Black, W.: Choice-set Definition in Patronage Modeling. Journal of Retailing 60 (Summer 1984): 63-85.

Blattberg, R., Briesch, R., and Fox, E.: Les questions en suspens dans le domaine de la promotion des ventes. Recherche et Applications en Marketing 9 (1994): 109-125.

Bucklin, R.E., and Lattin, J.M.: A Model of Product Category Competition Among Grocery Retailers. Journal of Retailing 68 (Fall 1992): 271-293.

Cox, A.D., and Cox, D.: Competing on Price: The Role of Retail Price Advertissements in Shaping Store-Price Image. Journal of Retailing 66 (1990): 428-445.

Desmet, P.: Promotion des ventes, du 13 à la douzaine au marketing direct. Nathan, Paris, France. 1992.

Desmet, P.: Portée et limites de l'utilisation du modèle logit pour l'étude des comportements d'achat. Recherche et Applications en Marketing 8 (1993): 65-78.

Desmet, P., and Volle, P.: The modelling and assessment of store loyalty performance with a simple-effect gravitational model, in EMAC Proceedings, Budapest, Hungary. 1996.

Diamond, W.: Just What a "Dollar's Worth"? Consumer Reactions to Price Discounts vs. Extra Product Promotions. Journal of Retailing 68 (Fall 1992): 254-270.

Ducrocq, C.: Concurrence et stratégies dans la distribution. Vuibert Entreprise, Paris, France. 1991.

Fader, P.S., Lattin, J.M., and Little, J.D.C.: Estimating Nonlinear Parameters in the Multinomial Logit Model. Marketing Science 11 (Fall 1992): 372-385.

Fotheringham, A.S., and Trew, R.: Chain Image and Store-choice Modeling: The Effects of Income and Race, Environment and Planning A 25 (1993): 179-196. 
Froloff-Brouche, L.: L'influence de la promotion des ventes sur le consommateur : un essai de conceptualisation. Recherche et Applications en Marketing 9 (1994): 45-65.

Ghosh, A.: Parameter Nonstationarity in Retail Choice Models. Journal of Business Research 12 (1984): $425-436$.

Gonül, F., and Srinivasan, K.: Modeling Multiple Sources of Heterogeneity in Multinomial Logit Models: Methodological and Managerial Issues. Marketing Science 12 (Summer 1993): 213-229.

Grover, R., and, Srinivasan V.: Evaluating the Multiple Effects of Retail Promotions on Brand Loyal and Brand Switching Segments. Journal of Marketing Research 29 (February 1992): 76-89.

Guadagni, P.M., and Little, J.D.C.: A Logit Model of Brand Choice Calibrated on Scanner Data. Journal of Marketing Research 2 (Summer 193): 203-238.

Gupta, S.: Impact of Sales Promotion on When, What and How Much to Buy. Journal of Marketing Research 25 (November 1988): 342-355.

Hardie, B.G.S., Johnson, E.J., and Fader, P.S.: Modeling Loss Aversion and Reference Dependence Effect on Brand Choice, Marketing Science 12, (Fall 1993): 378-394.

Henderson, C.M.: Promotion Heterogeneity and Consumer Learning : Refining the Deal-Proneness Construct, in Advances in Consumer Research 21, Association for Consumer Research. 1994, pp. 86-94.

Hildebrandt, L.: Store Image and the Prediction of Performance in Retailing. Journal of Business Research 17 (1988): $91-$ 100.

Hirschman, E., Greenberg, B., and Robertson, D.H.: The Intermarket Reliability of Retail Image Research: An Empirical Examination. Journal of Retailing 54 (Spring 1978): 3-12.

Hoch, S.J., Drèze, X., and Purk, M.E.: EDLP, Hi-Lo and Margin Arithmetic. Journal of Marketing 58 (October 1994): 1627.

Hubbard, R.: A Review of Selected Factors Conditioning Consumer Travel Behaviour. Journal of Consumer Research 5 (June 1978): 1-21.

Inman, J.J., McAlister, L., and Hoyer, W.D.: Promotion Signal: Proxy for a Price Cut? Journal of Consumer Research 17 (June 1990): 74-81.

Jallais, J., Orsoni J., and Fady, A.: Le marketing dans le commerce de détail, Vuibert Gestion, Paris. 1994.

Kahn, B.E., and Schmittlein, D.C.: The Relationship Between Purchases Made on Promotion and Shopping Trip Behavior. Journal of Retailing 68 (Fall 1992): 294-315.

Kargaonkar, P.K., Lund, D., and Price, B.: A Structural Equations Approach toward Examination of Store Attitude and Store Patronage Behavior. Journal of Retailing 61 (1985): 39-60.

Knox, S., and Walker, D.: Empirical Development in the Measurement of Involvement, Brand Loylty and Their Structural, Relationships in Grocery Markets, Working Paper, Cranfield School of Management (1995): 1-22.

Kumar, V., and Leone, R.P.: Measuring the Effect of Retail Store Promotions on Brand and Store Subsitution. Journal of Marketing Research 25 (May 1988): 178-185.

Laurent, G., and Kapferer, J.N.: Measuring Consumer Involvement Profiles. Journal of Marketing Research 22 (February 1985): 41-53.

Lichstenstein, D.R., Ridgway, N.M., and Netemeyer, R.G.: Price Perceptions and Consumer Shopping Behavior: A Field Study. Journal of Marketing Research 30 (May 1993): 234-245.

Lutz, R.J.: The Role of Attitude Theory in Marketing, in Handbook of Consumer Behavior. T.S., Robertson, and H.H., Kassarjian eds., Prentice Hall. 1991, pp. 317-339.

Mazundar, T., and Yun, S.Y.: Consumer Evaluations of Multiple versus Single Price Change. Journal of Consumer Research 20 (December 1993): 411-450.

McFadden, D.: Quantal Choice: A survey. Annals of Economic and Social Measurements 5 (1986): 363-390.

Meyer, R.J., and, Kahn, B.E.: Probabilistic Models of Consumer Choice Behavior, in Handbook of Consumer Behavior, T.S., Robertson, and H.H., Kassarjian eds., Prentice Hall. 1991.

Mittal, B.: An Integrated Framework for Relating Diverse Consumer Characteristics to Supermarket Coupon Redemption. Journal of Marketing Research 31 (November 1994): 533-544.

Moriarty, M.: Feature Advertising-Price Interaction Effects in the Retail Environment. Journal of Retailing 59 (Summer 1983): 80-98. 
Mulhern, F.J., and Leone, R.P.: Retail Promotional Advertising, Do the Number of Deal Items and Size of the Deal Discount Affect Store Performnance. Journal of Business Research 21 (1990): 179-194.

Mulhern, F.J., and Padgett, D.T.: The Relationship Between Retail Price Promotions and Regular Price Purchases. Journal of Marketing 59 (October 1995): 83-90.

Mulhern, Francis J.: Retail marketing: From distribution to integration. International Journal of Research in Marketing 14 (May 1997): 103-124.

Ortmeyer, G., Lattin, J., and Montgomery, D.: Individual Differences in Response to Consumer Promotions. International Journal of Research in Marketing 8 (1991): 169-185.

Peterson, R.A., and Power, J.D.: Service Involvement and Customer Satisfaction, in International Research Seminar in Marketing, P., Eiglier, and E., Langeard eds., La Londe, IAE d'Aix-Marseille, France. 1995, pp. 415-430.

Punj, G.N., and Stewart, D.W.: An Interaction Framework of Consumer Decision Making. Journal of Consumer Research 10 (September 1983): 181-196.

Rust, R.T., and Donthu, N.: Capturing Geographically Localized Misspecification Error in Retail Store Choice Models. Journal of Marketing Research 32 (February 1995): 103-110.

Schneider, L.G., and Currim, I.S.: Consumer Purchase Behaviors Associated with Active and Passive Deal-Proneness. International Journal of Research in Marketing 8 (1991): 205-222.

Schindler, R.: How Cents-off Coupons Motivate the Consumer, in Research on Sales Promotion, K., Jocz ed., Cambridge, MA, Marketing Science Institute. 1984.

Sharma, S., Durand, R.M., and Gur-Arie, O.: Identification and Analysis of Moderator Variables. Journal of Marketing Research 17 (August 1981): 291-300.

Sheth, J.: An Integrative Theory of Patronage Preference and Behavior, in Patronage Behavior and Retail Management, Darden, W.R., and R.F., Lush eds., Elsevier, North-Holland, NY. 1983, pp. 9-28.

Shimp, T.A., and Kavas, A.: The Theory of Reasoned Action Applied to Coupon Usage. Journal of Consumer Research 11 (December 1984): 795-809.

Siddarth, S., Bucklin, R.E., and Morrison, D.G.: Making the Cut: Modeling and Analysing Choice Set Restriction in Scanner Panel Data. Journal of Marketing Research 32 (August 1995): 255-266.

Strazziéri, A.: Mesurer l'implication durable vis-àvis d'un produit indépendamment du risque perçu. Recherche et Applications en Marketing 9 (1994): 73-91.

Tat, P.K.: Rebate Usage: A Motivational Perspective. Psychology and Marketing 11 (January 1994): 15-26.

Tauber, E.M.: Why Do People Shop. Journal of Marketing 36 (October 1972): 46-59.

Urbany, J.E., Dickson, P.R., and Kalapurakal, R.: Price Search in the Retail Grocery Market. Journal of Marketing 60 (April 1996): 91-104.

Walters, R.G.: Retail Promotions and Retail Performance: a Test of Some Key Hypotheses. Journal of Retailing 64 (Summer 1988): 153-179.

Walters, R.G.: Assessing the Impact of Retail Price Promotions on Product Substitution, Complementary, Purchase and Interstore Sales Deplacement. Journal of Marketing 55 (April 1991): 17-28.

Walters, R.G., and McKenzie, S.B.: A Structural Equations Analysis of the Impact of Price Promotions on Store Performance. Journal of Marketing Research 25 (February 1988): 51-63.

Walters, R.G., and Rinne, H.K.: An Empirical Investigation into the Impact of Price Promotions on Retail Store Performance. Journal of Retailing 62 (Fall 1986).

Westbrook, R.A., and Black, W.C.: A Motivation-Based Shopper Typology. Journal of Retailing 61 (1985): 78-103.

Yadav, M.S.: How Buyers Evaluate Product Bundles: A Model of Anchoring and Adjustment. Journal of Consumer Research 21 (September 1994): 342-353. 


\begin{tabular}{|l|}
\hline I particularly like shopping for groceries (INVOLVE_1) \\
\hline Shopping for groceries is an activity to which I attribute a special importance (INVOLVE_2) \\
\hline One can say shopping for groceries is an activity I am interested in (INVOLVE_3) \\
\hline Buying products on promotion is a way to be a smart shopper (ATTITUDE_1) \\
\hline Buying products on promotion gives me a feeling of satisfaction (ATTITUDE_2) \\
\hline I usually spot some products presented in the flyers, in order to buy them once in the \\
store (INFOSEARCH_1) \\
\hline I usually flick through the flyers I receive in my letter-box (INFOSEARCH_2) \\
\hline I carefully read the flyers to compare prices between stores (INFOSEARCH_3) \\
\hline
\end{tabular}


${ }^{1}$ In the United-States, newspapers and weekly supplements are a key source of information; based on observations, it is not relevant to consider these sources of information for France.

${ }^{2}$ These main limitations are: (i) independence of consecutive choices (McFadden, 1986), (ii) contextual independence of choices - i.e., independence of irrelevant alternatives (e.g., Meyer and Kahn, 1991), (iii) homogeneous consideration sets (Black, 1984; Andrews and Srinivasan, 1995), (iv) homogeneous preference toward choice alternatives and homogeneous response coefficients (Gonül and Srinivasan, 1993), (v) geographical stationarity of the estimated parameters (Ghosh, 1984; Rust and Donthu, 1995).

${ }^{3}$ Friday morning was chosen as it is a weekly peak for communication.

${ }^{4}$ The translated items presented here are only indicative.

${ }^{5}$ Store dummy variables are not commented here, as they do not participate to the test of the research hypothesis.

${ }^{6}$ The main effect of store loyalty has been numbered $\mathrm{H} 7$ when exposing the hypotheses; we expect this is not too confusing for the reader.

${ }^{77}$ We also check for the effect of colinearity between the explanatory variables; for doing so, we introduce each promotional variable on its own in the loyalty-only base model, i.e., we estimated 6 new logit models. In the main, our conclusions remain identical, except for the long range products (the parameter is now significant at $p<0.001$ ) and for the radio $\mathrm{x}$ outdoor advertising interaction term (not significant anymore). Although the results are rather robust, some parameters may become significant (or inversely), because the effects are weak.

${ }^{8}$ The estimation of these interaction terms with the number of promoted products (PROMO) instead of the sheer number of advertised products (PROD) yield the same result.

${ }^{9}$ These items were (illustrative translation): I regularly visit various stores to benefit from special offers and, (inverted) I stick to my usual store, whatever products other stores may promote. This construct was not used earlier in this research as it is clearly another dependent variable, that needs to be investigated separately (e.g., structural equations).

${ }^{10}$ The results are not reported here because of space constraint, but are available from the author.

${ }^{11}$ i.e., 24 weeks times 5 stores. 